\title{
Designing a Video as a Tool to Promote Zoom Hotel Jemursari Surabaya to its Target Market
}

\author{
Rendy Darmawan \\ English Department, Faculty of Letters, Petra Christian University, Siwalankerto 121-131, Surabaya \\ 60236, Indonesia. \\ E-mail: rendydarmawant13@gmail.com
}

\begin{abstract}
This is a creative thesis report on a problem that Zoom Hotel Jemursari Surabaya has. Zoom Hotel Jemursari is located at Jl. Raya Jemursari Surabaya. As a hotel the main product of Zoom Hotel Jemursari is the rooms it provides for the guests. The main problem of this hotel regarding the salespersons have difficulties to convince the customers because they do not have a promotional tool that can support them to provide more interesting information about Zoom Hotel Jemursari. Regarding this problem, I decided to make a promotional video as the solution for this problems. However, due to current pandemic, this thesis would cover questionnaire for the data and/until the act of creating the storyline for the promotional video. This promotional video will be a beneficial tool for Zoom Hotel Jemrusari's salespersons because this tool will support the salespersons to convince the customers by providing more interesting information using this promotional video.
\end{abstract}

Keywords: Promotional tool, promotional video, storylines, questionnaire, USP, Hotel,

\section{INTRODUCTION}

Zoom Hotel Jemursari was established in 2014 as a hotel. This hotel is located at $\mathrm{Jl}$. Raya Jemursari no. 109 B-C Surabaya. As a hotel the main product of Zoom Hotel Jemursari is the rooms it provides for the guests. Therefore, Zoom Hotel Jemursari provides 80 smart rooms with three types of rooms such as sleeping room, comfort room and dreaming room. In addition, Zoom Hotel Jemursari provides its guests with a variety of facilities as well, such as rooms for seminars and meetings, and restaurant. As for the seminars and meetings, this hotel has a total of two types of room, each with different dimensions, capacities, benefits and facilities. As of today, Zoom hotel has three branches in some big cities in Indonesia which are in Surabaya and in Samarinda. In Surabaya there are Zoom hotel Jemursari and Dharmahusada, while in Samarinda they use the name as Zoom Hotel Mulawarman. As a hotel that is currently operating in a big city like Surabaya, Zoom Hotel Jemursari obviously has some competitors that have to be paid attention to. The competitors are Yello Hotel,Zest Hotel and Luminor Hotel Jemursari. Those hotels are located close to one another, and they share almost the same quality, price and facilities to be provided to the customers.

Within three months of my doing the internship in Zoom Hotel Jemursari, I found a problem concerning the hotel. The main problem is that the salespersons have difficulties to convince the customers. This inability is caused by the lack of appropriate tools to explain and provide more interesting information about the hotel to the customers. The salespersons did not have promotional tools that can support them to show more interesting information about Zoom Hotel Jemursari. As my experience when I accompanied salespersons to meet customers, the salespersons did a good job to convince the customers by talking and showing the brochure. However, some customers still were not interested. In this case the salesperson told the customers they can see more interesting information in Zoom Hotel's website with a purpose to convince the customers. Therefore, the salesperson used website as their promotional tool to convince the customers. As what I have observed, in Zoom Hotel's website there are three Zoom Hotel such as Zoom Hotel Dharmahusada Surabaya, Zoom Hotel Jemursari Surabaya and Zoom Hotel Mulawarman Samarinda. Those three Zoom Hotels share almost the same quality, 
Darmawan: "Designing a Video as a Tool to Promote Zoom Hotel Jemursari Surabaya to its Target Market

price and facilities to be provided to the customers. However; Zoom Hotel Dharmahusada is more complete than the others. This can be a problem for Zoom Hotel Jemursari because when customers see the website and they will be more interested in Zoom Hotel Dharmahusada and not in Zoom Hotel Jemursari. Due to this problem, I think the salespersons need a new promotional tool that can support them to explain and give more interesting information about Zoom Hotel Jemursari in order to convince the customers and prospects.

I decided to make a promotional video as my Creative Thesis. Due to this problem, I will make a promotional video to overcome this obstacle. A resolution for this issue is important because without a proper video promotion, the Marketing staff and sales staff will have trouble in doing their most important job: promoting their rooms and products to the customers. However, due to COVID-19 outbreak, I do not have to submit the video. Instead, I have to submit the storylines or storyboards (which consist of at least, description of the scene (actors \& action), dialogue, and props/visual effect \& sample pictures). A storyline is important, because it will help me to plan the video and directions for the videographer to produce the idea of the promotional video from the shooting, set up, cut and to edit the video into the final product. There are two reasons why I chose promotional video to overcome this obstacle.

First, most of customers did not want to spend much of their time by reading a brochure, booklet or searching to the website. Therefore, the salesperson had to explain clearly in a short time. In this case the salespersons needed a tool that can support them in order to be able to convince the customers efficiently.

Second, promotional video is the right solution because in order to convince the customers, salesperson need to provide experience of how Zoom Hotel Jemursari's unique selling products looks like when the customers watch the promotional video. With the right content, promotional video will be the best way to give a real glimpse of what Zoom Hotel Jemursari's unique selling products are. After the customers watch the promotional video, they will have expectations of what benefits they will get if they agree to stay in buy Zoom Hotel Jemursari.

\section{Literature Review}

\section{Hotel}

According to the experts the definition of hotel: Rumekso (2002:2) "housekeeping hotel" states that hotel is a building which hires the rooms with the facilities such as food and beverage which is run well to get the benefits. Sulastiyono (2007:3) "manajemen penyelenggaraan hotel" states that hotel is an accommodation that gives the facilities like rooms, food and beverage and other supporting facilities such as sport area, and laundry.

According to Tarmoezi and Manurung (2007:1) hotel is a building that provides the rooms with the supporting facilities such as the food and beverage. Based on the definition, hotel does not only sell the room but hotel is one of accommodation that sell the other facilities.

\section{Branding}

A brand can be named a product or services, logo or a visual one represents to the public, or a customer's belief about a certain products or services (Healey, 2008, p,7). A brand 
that exists in a customers' mind: it is a collection of a perception about something. In other words, brand is what customers think of it.

According to Alina Wheeler (2013, p. 6), branding is a consistent and continuous effort to build brand awareness and expand customer loyalty. In other words, branding is about seizing every opportunity to tell why customers should choose certain brand over another. Many companies use branding because it gives the company a desire to lead, beats the competition, and gives employees the best tools to reach customers. By doing branding, the company can also identify and emphasize its uniqueness and strengths to differentiate and make the company stand out from the competitors. A brand that stands out from a densely crowded marketplace is a strong brand (2013, p.2).

\section{Target Market}

It is a well-known fact that target market takes an important role in the process of attracting customers to the act of purchasing a product. According to Cooper and Grutzner (2008, p.60), "tips and traps for marketing your business" a target market is a group of people with similar characteristics that result in similar purchasing patterns. It is a known fact that not everyone likes the same things or consumes them in the same way. Therefore, every business needs to carefully identify and understand the characteristics of its target market to be able to get the best result, or driving them to the act of purchasing. In addition, determining the suitable target market is often considered using the demographic, attitudes and opinions, need states, emotional needs, lifestyles, shopping occasion, type of company and job description of the target market.

\section{Promotion}

Promotion is one of the components of the Marketing Mix that consists of promotion, product, price, and place. Based on the book of Richard J. Semenik "Promotion and Integrated Marketing Communication", promotion is "the communication process in marketing that is used to create a favorable predisposition toward a brand of product or service, an idea, or even a person. (Semenik, 2002, p.7)". The most common kind of promotion is a promotion for a brand of products or services. In this report I will use the theory to promote a company.

McCabe (2009), "argues that there are three main streams of objection for promotional goal setting" The first is for marketing goals. It is an achievement of sales of the product to the customers. The second is for corporate goals. It is issues that are related to market share or volumes of sales, profitability and revenue. And the third is communication goals. That is relating to the image, reputation and attitudes of the stakeholders towards the organization.

\section{Promotional Video}

According to meriam-webster.com, "promotion is the act or fact of being raised in position or rank" and "the act of furthering the growth on development or something". Video is "a digital recording of an image or set of images (such as a movie or animation)".

A promotional video or promo video is a video used for the express purpose of promoting a specific marketing initiative, sale, or event. Promos are often similar in style and tone to a teaser video, where we grab our audience's attention and draw them in to learn more. According to Yael Klass promotional video is a business video with the intent to promote products and services to customers and prospects. By using promotional video, the hotel can introduce, describe and even promote its products, services and facilities to its customers or prospects. 
Darmawan: "Designing a Video as a Tool to Promote Zoom Hotel Jemursari Surabaya to its Target Market

According to Jonathan Barnard, The Head of Forecasting at Zenith, said of this trend: "The consumption of online video is growing rapidly, and the average person will spend half as much time viewing online video as they spend viewing conventional television this year. This fast-expanding supply of audiences is fuelling rapid growth in demand from advertisers, making online video the fastest-growing digital channel by advertising expenditure." Many marketers use promotional video as their marketing tool because they found out the data that people are easily interested in visual advertisement such as promotional video.

\section{Unique Selling Point (USP)}

According to https://www.entrepreneur.com, Unique Selling Point (USP) is the factor or consideration proven by the seller as a reason that the product or service is better than others. I can conclude that unique selling point is the values that differentiate one product or service than others.

Knowing the USP of a products or service is very important. According to Owen Gough from https://www.growthbusiness.co.uk, it is very important to know the USP because it will help the branding and marketing become stronger because it will give a clear vision of the company and the message we want to deliver. Besides, the USPs will make the company know a clear direction to build a business personality. This will also make the customers and business community to remember the brand and its reputation

\section{METHOD}

\section{Respondents' Criteria}

The respondents of the survey were Zoom Hotel Jemursari's guests. There were 10 respondents from 4 main categories of Zoom Hotel Jemursari's customers. Based on what I have experienced during my internship in Zoom Hotel Jemursari, there are four main categories who often buy Zoom Hotel Jemursari products and services. Those are corporations, governments, groups of people and individuals. the questionnaire was fulfilled by three people from corporations, three people from government, three people from a group and one person from individual categories.

The respondents from corporations and government categories are the representative of the company or institution. The representatives are those people whose job is to manage accommodation for the events that they hold. It is important to get feedbacks from the representative instead of the guests because the representatives are the one who decide to buy Zoom Hotel Jemursari's services and products.

\section{Methods of Data Collection}

The data was collected by giving questionnaires to the customers. Due to the pandemic of COVID-19, the questionnaire was done online via google form. The questionnaire was shared to the Zoom Hotel Jemursari's customers based on each category. For the corporation and government, the questionnaire was fulfilled by the representatives.

There are 3 sections in the questionnaire. The first section is about personal data of the respondent. In this section there are several questions about the background of the customers such as institution name, occupancy or position in the institution, residence, age, and how many times they have visited Zoom Hotel Jemursari. 
The second section of the questionnaire is about the hotel. This section shows the customers' perception about the facilities in Zoom Hotel Jemursari such as the main rooms, meeting rooms, and Z-lounge resto. Respondents can give their impression about the facilities.

The third section is about the marketing tool. In this section we would like to know how the customer know about Zoom Hotel Jemursari's marketing tools. This section will show what marketing tools that will be suitable for Zoom Hotel Jemursari in order to get more customer's interest.

\section{FINDING AND DISCUSSION}

The objective of making the questionnaire form is to identify the USP that can be used in my storylines for the promotional video in order to attract the customer's interest. The first section covers the questions, which include the questions to get the respondents personal background information. In order to get the reliable data, the respondents must be customers who have stayed at Zoom Hotel Jemursari at least 3 times or more from the last 6 months.

This is the result from the first section.

\begin{tabular}{|l|l|l|l|l|l|l|}
\hline Name & $\begin{array}{l}\text { Jenis } \\
\text { kelamin }\end{array}$ & Umur & $\begin{array}{l}\text { Pekerjaan atau } \\
\text { jabatan }\end{array}$ & $\begin{array}{l}\text { Nama } \\
\text { Perusahaan }\end{array}$ & Alamat & $\begin{array}{l}\text { Seberapa } \\
\text { sering anda } \\
\text { menikmati } \\
\text { layanan } \\
\text { dan fasilitas } \\
\text { Zoom Hotel } \\
\text { Jemursari? }\end{array}$ \\
\hline Andhika & Male & 21 & $\begin{array}{l}\text { Barista } \\
\text { Starbucks }\end{array}$ & $\begin{array}{l}\text { Starbuck } \\
\text { Indonesia }\end{array}$ & Surabaya & $\begin{array}{l}\text { Lumayan } \\
\text { sering }\end{array}$ \\
\hline $\begin{array}{l}\text { Farida } \\
\text { Komari } \\
\text { ah }\end{array}$ & Female & 40 & $\begin{array}{l}\text { Karyawan } \\
\text { Swasta }\end{array}$ & BCA & Surabaya & $\begin{array}{l}\text { Kadang- } \\
\text { kadang }\end{array}$ \\
\hline $\begin{array}{l}\text { Susi } \\
\text { Jamalud } \\
\text { in }\end{array}$ & Female & 37 & $\begin{array}{l}\text { Karyawan } \\
\text { Swasta }\end{array}$ & PT. Maspion & Surabaya & $\begin{array}{l}\text { Kadang- } \\
\text { kadang }\end{array}$ \\
\hline $\begin{array}{l}\text { Mart } \\
\text { Rifai }\end{array}$ & Male & 28 & $\begin{array}{l}\text { Barista } \\
\text { Starbucks }\end{array}$ & $\begin{array}{l}\text { Starbucks } \\
\text { Indonesia }\end{array}$ & Surabaya & $\begin{array}{l}\text { Kadang- } \\
\text { kadang }\end{array}$ \\
\hline Hapsari & Female & 27 & $\begin{array}{l}\text { Karyawan } \\
\text { swasta }\end{array}$ & $\begin{array}{l}\text { PT. Permata } \\
\text { Solusindo }\end{array}$ & Surabaya & Sering sekali \\
\hline $\begin{array}{l}\text { Nur } \\
\text { Aisyah }\end{array}$ & Female & 37 & Manager & PT. Maspion & Surabaya & Sering \\
\hline Ling & Female & 23 & Karyawan & BCA & Surabaya & $\begin{array}{l}\text { Kadang- } \\
\text { kadang }\end{array}$ \\
\hline Erwin & Male & 29 & $\begin{array}{l}\text { Karyawan } \\
\text { swasta }\end{array}$ & $\begin{array}{l}\text { Pabrik Integral } \\
\text { mabel }\end{array}$ & Sidoarjo & $\begin{array}{l}\text { Kadang- } \\
\text { kadang }\end{array}$ \\
\hline William & Male & 23 & Karyawan & PT. Maspion & Surabaya & $\begin{array}{l}\text { Lumayan } \\
\text { swaring }\end{array}$ \\
\hline $\begin{array}{l}\text { Nurmiat } \\
\text { i } \\
\text { Hendrat } \\
\text { a }\end{array}$ & Female & 41 & $\begin{array}{l}\text { Karyawan } \\
\text { Swasta }\end{array}$ & PT. Maspion & Surabaya & $\begin{array}{l}\text { Lumayan } \\
\text { Sering }\end{array}$ \\
\hline Fiton & Male & 40 & Manager & $\begin{array}{l}\text { Starbucks } \\
\text { Indonesia }\end{array}$ & Surabaya & $\begin{array}{l}\text { Kadang- } \\
\text { kadang }\end{array}$ \\
\hline
\end{tabular}


Darmawan: "Designing a Video as a Tool to Promote Zoom Hotel Jemursari Surabaya to its Target Market

As for the second result, the questions of the questionnaire are about the hotel. In this part the respondents can give their impression about the facilities.

8. Apakah anda mengetahui apa yang menarik dari fasilitas-fasilitas dan layanan di Zoom Hotel Jemursari?

11 tanggapan

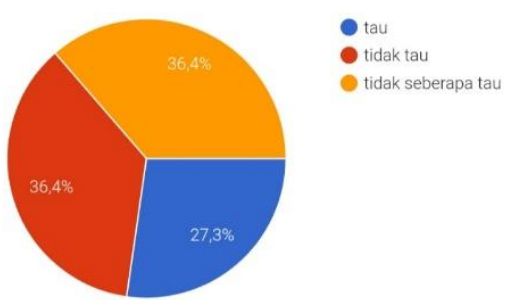

10. Apa kesan pertama anda mengenai ruang meeting Zoom Hotel Jemursari?

11 tanggapan

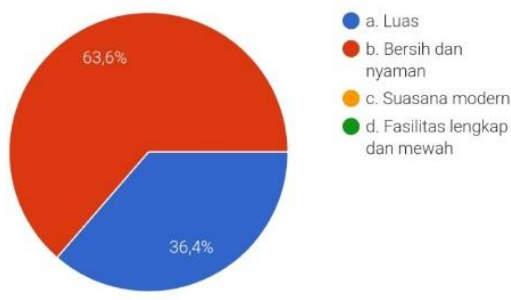

12. Manakah fasilitas Zoom Hotel Jemursari yang paling anda sukai?

11 tanggapan

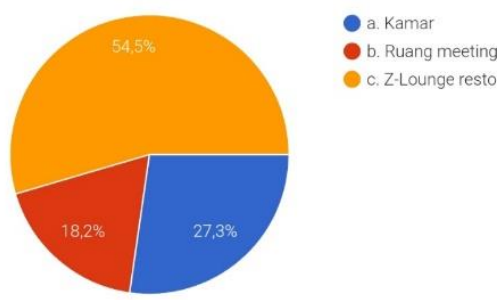

9. Apa kesan pertama anda mengenai kamar Zoom Hotel Jemursari?

11 tanggapan

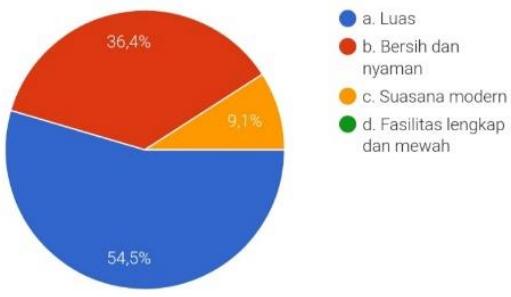

11. Apakah kesan pertama anda mengenai ZLounge resto?

11 tanggapan

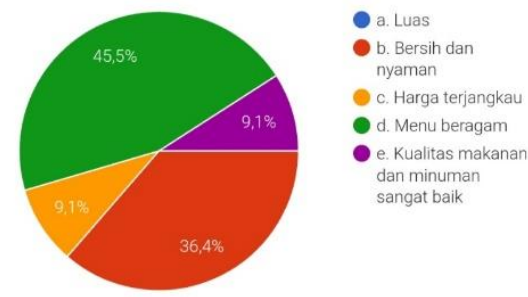

Pertanyaan Respons 11

13. Mengapa fasilitas tersebut menjadi favorit anda?

11 tanggapan

Nyaman

Karena saya sering menginap disini

ukuran kamarna luas dan bersih

karena ruangan itu sering saya gunakan untuk rapat

Karena pernah menghadiri event perusahaan

karena saya sering mengadakan rapat, dan juga arisan

Karena sering menginap

makanannya enak dan tempatnya bersih dan nyaman

ruangnya bersih dan nyaman dan makanan nya juga enak-enak. 


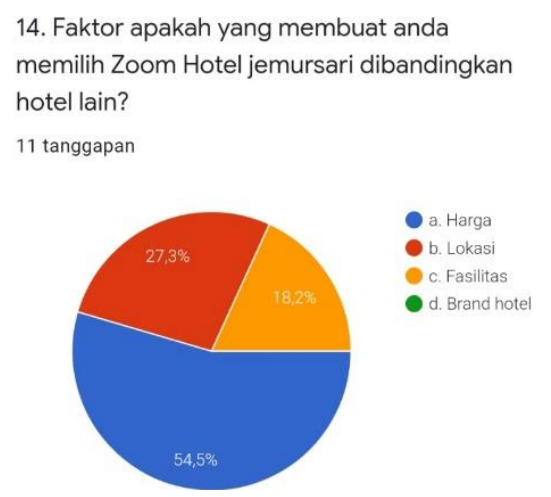

16. Faktor apa yang membuat anda memilih hotel tersebut?

11 tanggapan

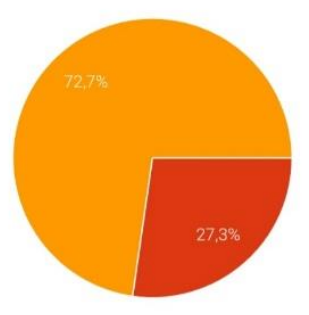

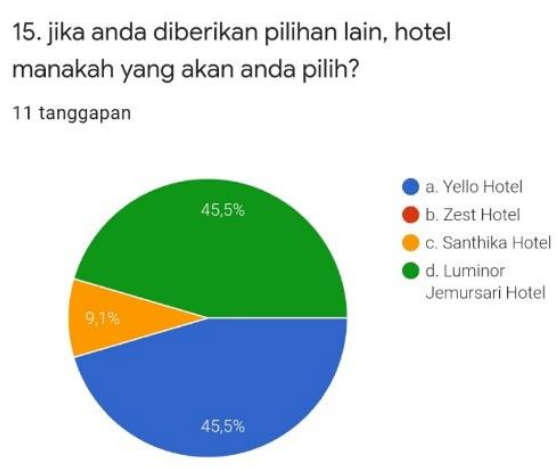

17. Apakah manfaat yang paling anda rasakan ketika memilih Zoom Hotel Jemursari sebagai pilihan akomodasi anda? 11 tanggapan

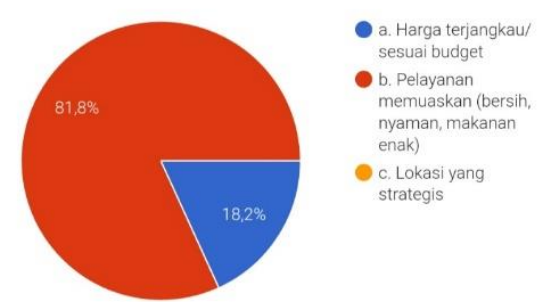

In the second section, respondents are asked about their point of view of Zoom Hotel Jemursari to find out the hotel's USP. Zoom Hotel Jemursari provides three facilities such as the main rooms, meeting rooms and Z-Lounge resto.

As for the main rooms, this hotel has advantages of its room's capacity and size because the majority of the respondents chose big capacity over the others choices.

As for the meetings rooms, four respondents chose big capacity and seven respondents chose comfortable and clean based on their experience from the meeting room.

As for the Z-Lounge resto, five respondents chose many varieties of menus, four respondents chose comfortable and clean and the rest chose Affordable prices and high quality of foods and beverage. From all the facilities, the majority of the respondents chose ZLounge resto as their favorite facilities. One of the reasons why they chose Z-Lounge resto is because the facilities is very comfortable place for social gathering such as arisan, birthday, family dinner and many more and the foods that Z-Lounge provides is delicious.

According to the respondents, the reason why they chose Zoom Hotel Jemursari over other hotels is because the price is affordable and if they are given a chance to choose another hotel they are going to choose Luminor Hotel Jemursari and Yello Hotel. The reason why they will choose those hotels because both hotels are more complete facilities such as swimming pool, game station, spa and gym center.

The last section of my questionnaire is about how the respondents' assumption about Zoom Hotel Jemursari's current marketing tools. 
Darmawan: "Designing a Video as a Tool to Promote Zoom Hotel Jemursari Surabaya to its Target Market

18. Dari siapakah anda mengetahui tentang Zoom Hotel Jemursari?

11 tanggapan

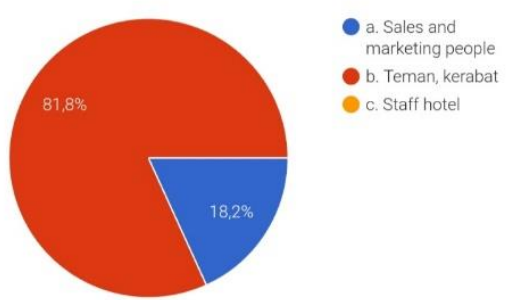

20. Apakah media promosi yang dimiliki Zoom Hotel Jemursari saat ini cukup menarik untuk memberikan informasi mengenai fasilitas dan layanan nya?

11 tanggapan

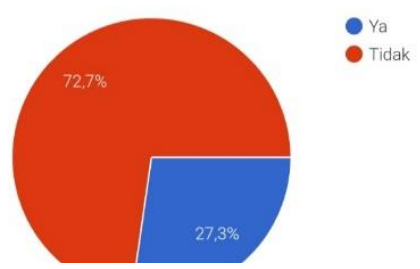

22. Apakah media promosi yang lebih menarik dan lengkap dapat membantu menjawab kebutuhan anda seputar produk dan fasilitas yang ada di Zoom Hotel Jemursari?

11 tanggapan

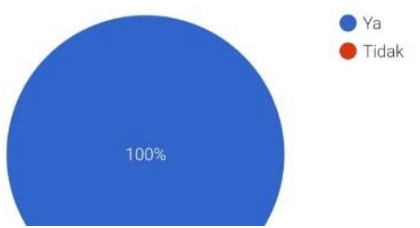

19. Bagaimana anda mengetahui tentang fasilitas dan layanan yang ada di Zoom Hotel Jemursari?

11 tanggapan

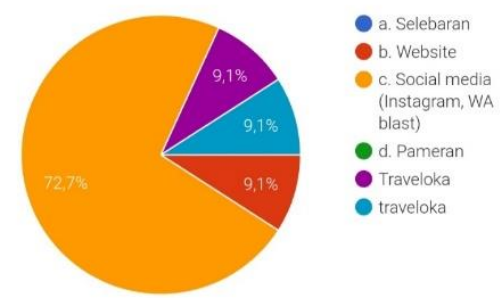

21. Apakah yang kurang dari media promosi yang dimiliki Zoom Hotel Jemursari saat ini? 11 tanggapan

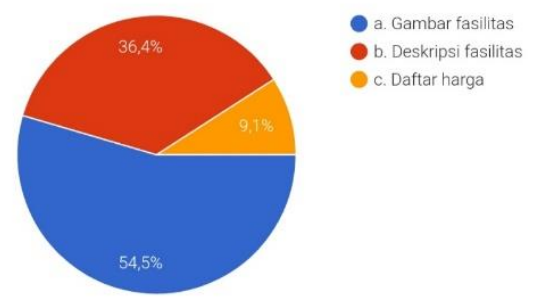

23. Menurut anda, apakah video promosi adalah media promosi yang tepat untuk membuat anda tertarik dengan product dan fasilitas yang di miliki Zoom Hotel Jemursari? 11 tanggapan

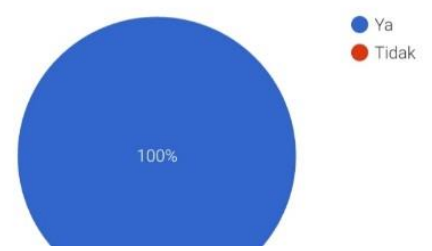

The result from the last section of my questionnaire which was fulfilled by the respondents revealed that indeed promotional video is the right marketing tool for Zoom Hotel Jemursari. All of the respondent agree that Zoom Hotel Jemursari's current marketing tools are not enough to show the experience from the hotel. They want to see more about the visual appearance that can make them interested in Zoom Hotel Jemursari. Indeed, by giving more visual appearance in the form of video will be more effective to attract customer's interest. 
Result of SWOT Analysis Based on Customer Interview and Survey

\begin{tabular}{|c|c|c|c|}
\hline STRENGTHS & WEAKNESSES & OPPORTUNITY & THREATS \\
\hline $\begin{array}{l}\text { 1. Zoom Hotel } \\
\text { Jemursari provides } \\
\text { big capacity in the } \\
\text { main rooms. } \\
\text { 2. Zoom Hotel } \\
\text { Jemursari's } \\
\text { meeting rooms is } \\
\text { comfortable and } \\
\text { clean } \\
\text { 3. Z-Lounge resto } \\
\text { is considered as the } \\
\text { favorites facility } \\
\text { because it is } \\
\text { comfortable and } \\
\text { clean for social } \\
\text { gathering such as } \\
\text { arisan, birthday, } \\
\text { family dinner and } \\
\text { many more and the } \\
\text { foods that Z- } \\
\text { Lounge provides is } \\
\text { delicious. }\end{array}$ & $\begin{array}{l}\text { 1. The facilities } \\
\text { which are } \\
\text { demanded by most } \\
\text { customers such as } \\
\text { swimming pool, } \\
\text { gym center, spa, } \\
\text { etc. are not } \\
\text { available in Zoom } \\
\text { Hotel Jemursari }\end{array}$ & $\begin{array}{l}\text { 1. The price that the } \\
\text { competitors have are } \\
\text { more expensive than the } \\
\text { price Zoom Hotel } \\
\text { Jemurari has. }\end{array}$ & $\begin{array}{l}\text { 1. There are several } \\
\text { hotels which } \\
\text { provide more } \\
\text { complete facilities } \\
\text { such as swimming } \\
\text { pool, game station } \\
\text { and gym. } \\
\text { 2. The competition } \\
\text { with the } \\
\text { competitors is quit } \\
\text { tight because } \\
\text { competitors are } \\
\text { targeting the same } \\
\text { target market. } \\
\text { 3. The competition } \\
\text { with the } \\
\text { competitors is quit } \\
\text { tight because those } \\
\text { hotels are located } \\
\text { close to each other }\end{array}$ \\
\hline
\end{tabular}

\section{The result of the SWOT}

The USP was found out through the SWOT analysis above. First, the data was categorized into four sub-categories; Strength, weakness, opportunity, and threat. After that, the strength would become the USP of Zoom Hotel Jemursari. The strength/USP then should be put and emphasized into the promotional video.

Based on the SWOT analysis above, there were three USP that were found in Zoom Hotel Jemursari, as listed below:

1. Zoom Hotel Jemursari has affordable price.

2. Zoom Hotel Jemursari provides big capacity in its main rooms and the meetingrooms.

3 Zoom Hotel Jemursari's Z-Lounge resto is the favorite facilities because of its high quality of the food and beverage.

\section{Storylines of the Promotional Video and its Explanation}

In this storylines of the promotional video there are five big scenes such as intro scene, the main room scene, the meeting room scene, the Z-Lounge resto scene and closing scene. In each scene consists its footages description about the facilities, products and services.

In the intro scene there are three footages. The first footage is the beginning of the video is the footage of the building and the logo. In this footage I take the advantage of the modern 
Darmawan: "Designing a Video as a Tool to Promote Zoom Hotel Jemursari Surabaya to its Target Market

building to use it as the opening in order to give interests experience when customers watch the video. This is important because from the beginning when we give a powerful opening the customers will have a good expectation about the video. In the second footage, I use the point of view (POV) method to show what it looks like when the customers come to Zoom Hotel Jemursari. In the screen will appear the person's POV of walking from the outside and there is the security who opens the door with a smile. After entering the lobby for check-in for the room, there are several staff hotels who is smiling to the camera. The last footage of the intro scene is that the POV as well but in the screen will appear the person's POV is viewing around to show the design of the hotel in the lobby. These footages will give the experience to the customers about Zoom Hotel Jemursari's interior design and services from the staff hotel.

Second scene is about main rooms. In this scene there are three footages about the visual appearance in the main rooms. There are three type of rooms such as sleeping room, comfort room and dreaming room. As for the sleeping room, in the screen will appear the view of the room and its facilities such as the bed, TV, WIFI connection, and the restroom. In this footage I add a text about the rooms "Sleeping Room" is soundproof room with additional space is designed for those who want to sleep peacefully. "Ideal for travelers in need of rest". As for the comfort room which is the second footage, in the screen will appear the view of the room and its facilities such as the bed, furniture, TV, WIFI connection, capacity of the room and the restroom. I also add text for the Comfort Room" lager capacity with additional space is more convenient. As for the last footage of this scene, I present the dreaming room in the same way like the previous footage. Dreaming room is the best room that Zoom Hotel Jemursari provides to its customers. In the screen will appear the view of the room and its facilities such as the bed, furniture, TV, WIFI connection, capacity of the room. Then I add text "Dreaming Room" The best room offers additional space and convenience "similar with a full studio apartment" The reason why I add this text in each footage because I want to show the value and benefit that these rooms have in order to attract the customer's interest.

The third scene is about the meeting rooms. In this scene there are three footages. The first footage is about the overview of meeting rooms. In the screen will appear the view of the meeting room and it facilities such as LCD, Microphone, Loud-speaker, white Screen, tables, chairs WIFI connections, air conditioner. In the screen I add text "Meeting room" comfortable and clean meeting room Equipped with high tech audio and video equipment. This text will show the values and the benefits that the meeting room has. The second footage is the act of customers who use the meeting rooms for formal meeting. In the screen will appear the view of the actors who are acting like in the formal meeting. There is one actor is acting like presenting and the rest of the actors are paying attention as the participants. This footage is important to show the comfortable experience to the customers that they can use this room for formal meeting. The last footage from this scene is the act of customers who use the meeting rooms for events such as seminar, make up class, technical meeting of sport event and many more. In the screen will appear the View of people who use this room for their events.

The fourth scene is about Z-Lounge resto. As for the first footage, I want to show the interior design of its facilities in the screen because the design is eye-catching and it will attract the customer's interests. In the screen will appear the person's POV is viewing around to show the design of Z-Lounge resto. I also add text "Z-Lounge Resto" Classic design and available for breakfast, Lunch and Dinner. The second footage is about the menu, food and beverage that ZLounge provides. In the screen will appear the view of the menu and all the favorite foods and the beverages. In the footage I add text "Available varieties of Indonesian and Chinese food and beverage". Then the last footage of this scene, I want to show the act of the customers who enjoy their moments and their food in Z-Lounge resto. In the screen will appear the view of the actors enjoying the food and there is a table with a full of family enjoying their moments. I also add text available for events such as birthday, family dinner and many more. 
The fifth scene is the closing. In this scene there are two footages. As for the first footage, in the screen will appear The person's POV is viewing, he comes out from lift, walking to the lobby and check-out and walking out to the door. In this footage I want to end the promo video as smooth as possible but still give the experience of the services in their last minutes in Zoom Hotel Jemursari. Then in the last footage will appear Zoom Hotel Jemursari's Logo and Contact information such as, address, customer services number and email. This is important because when they see the promotional video in social media or anywhere they will know how to book the hotel.

the main user of this promotional video are the salespersons and marketing staff. This promotional video will support them to convince the customers by showing the promotional video when the salesperson prospects customers. This promotional tool is suitable for Zoom Hotel jemursari to solve their problem in promoting its products because the promotional video contains more interesting information about the USP that can attract customer's interests. This promotional video is also available to be shared at social media such as Instagram, WA blast and YouTube.

\section{CONCLUSION}

For the Creative Thesis Project, I decided to make a promotional video that can be used to support the salesperson to convince the customers. I decided to go with this project as a response to the problem I found in Zoom Hotel Jemursari where I did my internship. In short, the problem that I found in this hotel is regarding the salespersons have difficulties to convince the customers because they do not have a promotional tool that can support them to provide more interesting information about the facilities, products and services that Zoom Hotel Jemursari has. By having a promotional video that contains more interesting information about Zoom Hotel Jemursari's USP, it will help and support the salesperson to convince the customers and Zoom Hotel Jemursari will get more customers by using the promotional video as its promotional tool.

\section{REFERENCES}

Attard, J. (2019, February 8). How to identify your target market. Retrieved March 30, 2020, from https://www.businessknowhow.com/marketing/targetmarket.htm

Bashin, Hitesh. (2017). Promotional Mix: what are the differences types of promotion? Retrieved March 15 2020, from https://www.marketing91.com/promotional-mix/

Cass, Jacob. (2018). * Benefits of Branding: why you need a strong brand? Retrieved December 11, 2019, from https://justcreative.com/2018/09/27/benefits-of-branding/

Cooper, S., Grutzner, F., \& Cooper, B. (2008). Tips \& traps for marketing your business. USA: McGraw-Hill Companies.

Grant, H. (February 6 2019). How to create the perfect promo video. Retrieved February 20 2020 from https://www.lemonlight.com/blog/how-to-create-the-perfect-promo-video/

Healey, Matthew. 2008. What is Branding? United Kingdom, Hove: Roto Vision SA.

Hubbard, L. (2019, February 19). Why is identifying the target market so important to a company. Retrieved April 30, 2020, from https://smallbusiness.chron.com/identifyingtarget-market-important-company-76792.html

Joanna, Carter (2020). Video Marketing Statistics to know for 2020. Retrieved April 62020 , from https://www.smartinsights.com/digital-marketing-platforms/videomarketing/video-marketing-statistics-to-know/

Scott McCabe (2009). Marketing Communications in tourism and Hospitality: Concepts, Strategies and Cases 
Darmawan: "Designing a Video as a Tool to Promote Zoom Hotel Jemursari Surabaya to its Target Market

Semenik, Richard. (2002). Promotion and Integrated Marketing Communication. Canada: South-Western Thomson Learning

Sodhi, Rajan (2006). 6 Steps to Bringing Your Brand to Life. Retrieved November 20, 2019 from http://rsodhi.blogspot.com/

Wheeler, A. (2013). Designing brand identity: an essential guide for the whole branding team. Canada: John Wiley \& Sons, Inc. 